\title{
Púrpura. Materialidad y simbolismo en la Edad Media*
}

\author{
Laura RodRíguez PEINAdo \\ Universidad Complutense de Madrid \\ Departamento de Historia del Arte I (Medieval) \\ lrpeinado@ghis.ucm.es
}

\section{RESUMEN}

Durante la Edad Media el término púrpura identificaba un concepto cromático entre los colores rojo, violeta y azul a la vez que podía designar un tipo de tejido específico, pero no estuvo asociado, como en la Antigüedad, al tinte extraído del murex, porque este fue sustituyéndose por otras sustancias tintóreas igualmente exclusivas y de coste elevado como el quermes. El color púrpura se identificó con el poder y la excelencia social y su valor simbólico se vinculó a los tintes con que teñir tejidos o manuscritos y a materiales como el pórfido, apreciado por sus cualidades matéricas y su color purpúreo.

Palabras clave: Púrpura, escarlata, murex, quermes, pórfido, tejidos, manuscritos, prestigio, poder.

\section{Purple. Materiality and Symbolism in the Middle Ages}

\begin{abstract}
During the Middle Ages the term purple identified a chromatic concept ranged among red, violet and blue, at the same time that it could designate a specific type of textile. Nevertheless, it was not associated, as it had been in Antiquity, to the murex dye, for it was gradually replaced by other dyestuffs as exclusive and expensive as the kermes. Purple was related to power and social excellence, and its symbolic value was linked to the dyes with which textiles or manuscripts were dyed, and to materials such as porphyry, appreciated for its materic qualities and its purplish colour.
\end{abstract}

Key words: Purple, scarlet, murex, kermes, porphyry, textiles, manuscripts, prestige, power.

\footnotetext{
* Este trabajo se incluye en el marco del Proyecto de Investigación del Ministerio de Economía y Competitividad HAR2008-04161.
} 
Genéricamente interpretamos púrpura como un color, pero hay que asociarlo igualmente con un tinte y la materia que lo produce. En la Edad Media era un término identificado con el poder, con la excelencia social y de alto valor simbólico, asumiendo solo alguno de los rasgos propios del significado de la palabra que en origen permitía evocar tanto al color como la materia de la que este se obtenía. Semánticamente

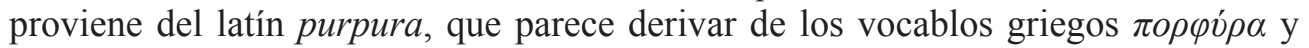
$\pi o ́ \rho \varphi v \rho о \varsigma$, posiblemente términos profesionales relacionados con tintoreros, derivados del que en origen describiera la especie que proporcionaba el colorante ${ }^{1}$. La importancia de la púrpura en la Antigüedad ha acaparado la atención de los estudiosos y no ha favorecido su estudio en la Edad $\mathrm{Media}^{2}$, por lo que hemos concebido este artículo con carácter explorativo sobre el papel de la púrpura y su significado en el ámbito medieval a falta, fundamentalmente, de estudios documentales e interpretativos por hacer ${ }^{3}$.

Necesariamente hay que hacer mención a la púrpura en la Antigüedad desde el punto de vista material y simbólico, periodo suficientemente estudiado por ser la época de mayor esplendor de este tinte, mientras que en el tiempo del que se ocupa este trabajo el uso de la materia tintórea utilizada en mayor medida en el mundo antiguo decayó en la Europa occidental, manteniéndose en Bizancio hasta la caída del Imperio en 1453.

La palabra púrpura hace referencia tanto a una sustancia tintórea como al color que de esta se obtiene o, más bien, a la tonalidad cromática que ha variado sustancialmente en el imaginario colectivo desde la Antigüedad a nuestros días. Philip Ball afirma que el término púrpura es un concepto cromático que en la Antigüedad podía variar del rojo azulado al rojo intenso ${ }^{4}$. Efectivamente, las tonalidades del color púrpura variaban en función de las sustancias tintóreas utilizadas ${ }^{5}$, obteniéndose colores de una gama entre los rojos, violáceos y azules, todos ellos de gran intensidad, muy saturados y de gran brillo, lo que hizo que fuesen apreciados por las clases privilegiadas tanto por su cromatismo como por la exclusividad del tinte con que se obtenían, lo que elevaba su coste. En la Edad Media, además de con un color, el vocablo se vinculó con un tipo de tejido determinado, no necesariamente de tonos purpúreos, sino de colores afines que asumieron asimismo un estatus de prestigio ${ }^{6}$.

1 P. FÉRNANDEZ URIEL, Púrpura. Del mercado al poder, Madrid, 2010, p. 57.

2 De este periodo únicamente podemos citar el trabajo de W. BORN, "Purple in the Middle Ages", Ciba Review, 4 (1937), pp. 119-123.

3 Quiero agradecer algunas aportaciones bibliográficas e iconográficas, de gran utilidad para la realización de este artículo, a Francisco de Asís García García.

4 P. BALL, La invención del color, Madrid, 2004, p. 257.

5 P. FERNÁNDEZ URIEL, op. cit., 2010, pp. 149-152.

6 Hay que tener en cuenta su afinidad cromática con el escarlata y azul e incluso con el verde en la Edad Media. Respecto al color azul, véase M. PASTOUREAU, Azul. Historia de un color, Barcelona, 2010. Para el color verde y su posición jerárquica como color de referencia de la autoridad política y religiosa, véase G. LORENZONI, "Il porfido. Marmo di porpora, in qualche esempio del Veneto", O. LONGO (ed.), La porpora. Realtà e immaginario di un colore simbolico. Atti del Convegno di Studio (Venezia, 24 e 25 otttobre 1996), Venecia, 1998, pp. 308-316. En cuanto a la transcendencia terminológica de color para referirse a materias, en el contexto de los textiles se da en otras ocasiones. Así, el término perse hace referencia a paños de origen 
El origen de la producción de la púrpura se remonta a la Antigüedad, en torno al Mediterráneo Oriental. Las fuentes mitológicas atribuyen su descubrimiento a Melqart, dios fenicio protector de las migraciones y de la navegación identificado con el Heracles griego. Cuenta la leyenda que estaban paseando por la orilla del mar el dios Melqart con su amada, la ninfa Tyrus, cuando un perro que les acompañaba mordió un caracol que se hallaba en la playa y lo partió en dos. El animal se tiñó la boca de un color intenso y Tyrus quedó tan admirada por su belleza que le dijo al dios que no lo aceptaría como su amante hasta que no le hubiera ofrecido un traje del mismo color. Melqart recogió entonces gran cantidad de estos moluscos y dio así origen a la industria tiria del teñido ${ }^{7}$. Como se deduce del mito, la púrpura se obtiene de gasterópodos marinos, concretamente de la familia de los muricidae o murex, cuya glándula hipobranquial segrega un mucus con cromógenos o pigmentos que sirven para su actividad celular y como mecanismo de defensa frente a otros organismos ${ }^{8}$. Esta sustancia, de color blanquecino, al contacto con el aire se torna amarilla para pasar después a verde, azul y finalmente al tono rojo-violáceo que conocemos como púrpura, apreciado por su solidez, sus tonos brillantes y la luz que reflejaban los tejidos teñidos con este tinte, por lo que su uso se convirtió en símbolo de lujo y estatus. Aunque según la leyenda su explotación comenzó en las costas de Tiro ${ }^{9}$ y fueron los fenicios quienes comerciaron tanto con el tinte como con tejidos de lana previamente teñidos, su origen está en torno a los años 1800-1600 a.C. en la cultura minoica, donde se ha detectado su uso como pigmento en la decoración de frescos y se han identificado conchas pulverizadas como conglomerado en los suelos de los palacios; pero en el primer milenio ya era explotada en todo el Mediterráneo y las costas atlánticas africanas, atribuyéndose a estas y a la zona levantina mediterránea su mayor volumen de producción ${ }^{10}$. También hay referencias de su uso en Asiria y

persa, sin interesar tanto su color como su calidad (J. GAGE, Color and meaning. Art, Science and Symbolism, Londres, 1999, p. 67 y $c f r$. nota 7, p. 282).

7 Plinio, Nat. Hist., IX, 125. P. FERNÁNDEZ URIEL, op. cit., 2010, pp. 53-54, refiere la derivación histórica de esta narración mítica.

8 D. CARDON, Le monde des teintures naturelles, París, 2003, pp. 421-467, analiza su química, sus métodos de extracción y de tintura, y los distintos moluscos de los que se obtiene. Respecto a las especies de murex utilizadas en la Antigüedad, en Roma tratadistas como Vitruvio (s. I a.C.) en De Architectura, (VII, xiii) y Plinio el Viejo (s. I d.C.) en su Naturalis Historia describen este producto y las recetas para su obtención. Plinio nombra tres tipos de moluscos como los más apropiados para obtener el tinte de mejor calidad: Murex Brandaris, que identificaba con el purpura, Murex Trunculus y Thais haemastoma, identificado con el buccinum. Según el autor, el color tirio se obtenía empapando la lana en una tina de extracto de purpura crudo y sin calentar pasándola después a uno de buccinum, resultando un color brillante con matices negruzcos, que era el más apreciado por los romanos (Nat. Hist., IX, 130).

9 E. GARCÍA VARGAS, "Tejidos y tintes como objetos de lujo y símbolo de estatus en la colonización fenicio-púnica. Una propuesta de contextualización histórica", B. COSTA (coord.), Aspectos suntuarios del mundo fenicio-púnico en la Península Ibérica. XXIV Jornadas de Arqueología fenicio-púnica, Ibiza, 2009, pp. 77-109.

10 Cabe reseñar los concheros excavados en las islas Baleares, Andalucía y el norte de África, sobre los que mencionamos algunos estudios: en C. ALFARO, J.P. WILD y B. COSTA (eds.), Purpureae Vestes I. Textiles y tintes del Mediterráneo en época romana, Valencia, 2004, los trabajos de: J. RAMON TORRES, "Evidències d'elaboració de porpra i fabricació de teixits a sa Caleta (Eivissa)", pp. 165-174; C. ALFARO GINER y E. TÉBAR MEGÍAS, “Aspectos históricos, económicos y técnicos de la producción de púrpura en la Ibiza romana”, pp. 195-210; M.S. CARRASCO PORRAS, "Estudio malacológico de las especies vinculadas 
Babilonia, así como en distintos pasajes de la Biblia ${ }^{11}$, mientras el verdadero interés de los egipcios por este tinte se produjo en el periodo helenístico ${ }^{12}$. Pero serían los monarcas persas quienes elevaran la púrpura al rango de símbolo oficial de la realeza considerándose emblema de poder y riqueza ${ }^{13}$. Después, Alejandro Magno adoptó para sí las insignias persas de poder -túnica púrpura con una banda blanca, clámide y diadema del mismo color con motivos blancos-, inaugurando una costumbre que se perpetuaría durante siglos como símbolo real ${ }^{14}$. En Roma fue signo de opulencia y rango social; durante la República solo tenían el privilegio de vestir de púrpura y oro los generales triunfantes, regulándose su utilización de acuerdo al rango de los usuarios. La adopción de indumentaria púrpura por parte de Julio César como símbolo de su poder fue mal vista por sus contrincantes, que veían en este hecho un gesto de su tiranía, pero a partir de entonces este color se fue poniendo de moda entre todas las clases sociales, utilizándose sucedáneos para teñir los motivos ornamentales. De esta realidad dan cuenta las recetas que se conservan para conseguir el color púrpura en los papiros X de Leyden y Estocolmo, del s. III d.C., porque si no se podía tener un tejido teñido con tan preciado tinte, al menos se podía emular su color ${ }^{15}$.

a la explotación de la púrpura halladas en Carthago-Nova (2 $2^{a}$ mitad del siglo III a.C.-I d.C.)”, pp. 211-214; B. COSTA y S. MORENO, "La producció de porpra en època romana a Ebusus. Excavacions al jaciment arqueològic de Pou del Lleó/Canal d'en Martí (Eivissa, Illes Balears)”, pp. 175-193; E. GARCÍA VARGAS, "Las pesquerías de la Bética durante el Imperio romano y la producción de púrpura", pp. 219-235. J.M. BLÁZQUEZ MARTÍNEZ, "La explotación de la púrpura en las costas atlánticas de Mauritania, Tingitania y Canarias. Nuevas aportaciones", Anuario de Estudios Atlánticos, 50, (2004), pp. 687-704; y D. BERNAL (ed.), Arqueología de la pesca en el Estrecho de Gibraltar. De la Prehistoria al fin del mundo antiguo, Madrid, 2009. Para una síntesis, P. FÉRNÁNDEZ URIEL, op. cit., 2010, pp. 222-238. En estos concheros, las especies de estas familias más abundantes son el Murex Brandaris y el Murex Trunculus y la presencia de otras especies en menores cantidades puede deberse a su utilización para extraer púrpura de menor calidad. Así parece que la Thais haemastoma producía tintes de calidad inferior.

11 Para la mención de la púrpura en los textos bíblicos, véase G. FILORAMO, "Variazioni simboliche sul tema della porpora nel cristianesimo antico", O. LONGO (ed.), op. cit., 1998, pp. 231-233. Asimismo, en el Protoevangelio de Santiago y en el Evangelio Armenio de la Infancia se dice que la Virgen hilaba púrpura y escarlata en el templo, las materias más preciosas. Hay que tener en cuenta lo que advierte Michel Pastoureau sobre las traducciones de los términos de color en textos antiguos, así donde en hebreo dice "rico", el latín medieval traduce por purpureus y las lenguas vulgares por púrpura: M. PASTOUREAU, Una historia simbólica de la Edad Media occidental, Buenos Aires, 2006, p. 149, nota 3.

12 Para la historia de la púrpura en la Antigüedad véase M. REINHOLD, History of Purple as a Status Symbol in Antiquity, vol. 116 de Latomus, Bruselas, 1970; P. FERNÁNDEZ URIEL, op. cit., 2010, pp. 207238, también da noticias sobre su explotación, centros de producción y uso durante la Antigüedad.

13 M. REINHOLD, op. cit., 1970, pp. 18-19. Pero es en una tableta cretense del lineal B donde se emplea por primera vez la expresión "púrpura real".

14 Ibid., p. 30.

15 E. RENNA, "Ricette per succedanei della porpora in due papyri greci", O. LONGO (ed.), op. cit., 1998, pp. 133-147; E.R. CALEY, "The Leyden papyrus X: an English translation with brief notes", Journal of Chemical Education, III, 10 (1926), pp. 1149-1166; E.R. CALEY, "The Stockholm Papyrus: an English Translation with brief notes", Journal of Chemical Education, IV, 8 (1927), pp. 979-1002. En los tejidos de la Antigüedad Tardía procedentes de Egipto, se ha comprobado mediante análisis de tintes que el color púrpura se obtiene con la mezcla de rojo y azul obtenido, principalmente, a partir de rubia e índigo. Véase L. RODRÍGUEZ PEINADO, A. CABRERA y E. PARRA, "Egyptian textiles from Late Antiquity and the Early Middle Ages in Spanish museums: results from three interdisciplinary research projects", A. DE MOOR, C. FLUCK y P. LINSCHEID (eds.), Drawing the threads together. Textiles and footwear of the 1st millennium AD from Egypt, Tielt, 2013, p. 115. 
Su cotización llegó a igualar o superar a la del oro por la laboriosidad de su extracción ${ }^{16}$. Del valor de esta sustancia usada como tinte da idea su manipulación. Así, aunque en los procedimientos de tinción la púrpura podía teñir la lana antes de ser hilada, generalmente se teñía después de hilarse por las pérdidas de materia que se producen durante el proceso; y para tejer, las urdimbre podían teñirse con otros colorantes reservándose esta preciada tintura para las tramas visibles, como se ha podido comprobar en algunos tejidos de Palmira ${ }^{17}$.

En la época imperial, los ricos tejidos de púrpura se pusieron de moda entre las clases sociales más acomodadas, lo que propició numerosas críticas por parte de los filósofos y un uso restrictivo a particulares al ser dotada de un valor simbólico en relación con el princeps. Cuando Diocleciano y Constantino tomaron medidas para que se regulase su empleo, prohibiéndose las sedas de este color fuera del círculo imperial y estableciéndose un monopolio imperial en su producción donde se reservaba para la dignidad imperial el sacer murex o "púrpura sagrada", los púrpura rojos-violeta -blatta y oxyblatta- y los azules-violeta -amethystina y hyacinthea-, no hacían más que llevar a término una política que confirmaba la identificación de la púrpura con el poder imperial ${ }^{18}$.

Al tiempo que Diocleciano instituyó la ceremonia de la adoratio purpurae, que marcaba la solemnidad mística de las audiencias imperiales, aparece en los textos el término de divina purpura aplicada a la indumentaria imperial, convertida en emblema de poder absoluto ${ }^{19}$, a lo que responden las palabras de Juan Crisóstomo, que dice, "solo al emperador le es otorgado llevar la púrpura y la diadema en su cabeza"20. Como símbolo de poder imperial y con carácter ceremonial continuará utilizándose en Bizancio. Los emperadores eran purpuratus -revestidos de púrpura-, la expresión tomar la púrpura - purpura sumsit- significaba alcanzar el poder supremo y el

16 Hay que tener en cuenta que solo se pueden extraer de una a tres gotas de cada molusco y que para obtener un gramo de tinte seco, que permite teñir unos 100 gramos de lana, se necesitan más de 10.000 especímenes. Véase D. DAVANZO POLI, "La porpora presso bizantini, copti e cristiani”, O. LONGO (ed.), op. cit., 1998, p. 409. En el Edicto de Precios Máximos de Diocleciano se valora la seda púrpura en 150.000 denarios, y mientras la libra de lana teñida con este tinte se valoraba en 50.000 denarios, el valor de la libra de oro eran 16.000 denarios. Véase A. CARILE, "Produzione e usi della porpora nell'impero bizantino", O. LONGO (ed.), op. cit., 1998, p. 251.

17 Teintures précieuses de la Méditerranée. Pourpre-Kermès-Pastel / Tintes preciosos del Mediterráneo. Púrpura-Quermes-Pastel, Musée des Beaux Arts de Carcassonne - Centre de Documentació i Museu Tèxtil de Terrasa, 1999, cat. 16, pp. 89-90. La ciudad de Palmira estaba dentro de las rutas caravaneras y en sus tumbas fueron descubiertos en los años 30 del siglo pasado más de 2.000 fragmentos de tejidos datados entre los siglos I a.C. y III d.C., reflejando el lujo de las élites locales. Son tejidos de diversa procedencia, realizados con diferentes fibras y técnicas, presentan un brillante colorido destacando los púrpura por ser el conjunto conocido más numeroso de la Antigüedad, y aunque no se puede precisar el origen de los tejidos teñidos con este rico tinte, permiten demostrar la voluntad de sus propietarios por exhibir su estatus incluso más allá de la muerte.

18 Parece evidente, a partir de la interpretación textual, que la población distinguía las clases de púrpura y sus calidades. Véase C.M. BOOKER, "The codex purpureus and its role as an imago regis in Late Antiquity", C. DEROUX (ed.), Studies in latin literature and roman history, vol. 239 de Latomus, Bruselas, 1997, p. 470.

19 L. BESSONE, "La porpora a Roma", O. LONGO (ed.), op. cit., 1998, pp. 188-202. Véase también el clásico estudio de M. REINHOLD, op. cit., 1970, pp. 62-65.

20 In paraliticum, 4 (cfr. P. FERNÁNDEZ URIEL, op. cit., 2010, p. 278). 
aniversario de la investidura imperial -dia natalis purpuram - se celebraba con gran boato $^{21}$.

En los gineceos imperiales bizantinos se manufacturaban sedas teñidas de púrpura para abastecer las necesidades de la familia imperial, entre las que también se encontraban los regalos con que obsequiar a sus cortesanos y embajadas extranjeras ${ }^{22}$. Su producción se mantuvo con este carácter hasta su caída en poder de los turcos en $1453^{23}$, pero la disminución de la producción desde los siglos VIII-IX dio lugar a que las recetas poco a poco fuesen sustituyendo el murex por otras sustancias tintóreas con las que se podía obtener el color ${ }^{24}$. La Toma de Constantinopla por los cruzados en 1204 propició una abrupta caída en la producción de este tinte ${ }^{25}$.

Como color imperial vinculado al poder, en Bizancio el púrpura no solo se utilizó en los textiles, también se impuso en otros soportes. Los codicilos y documentos diplomáticos más solemnes se teñían de este color $^{26}$. Del s. VI se conservan códices purpúreos en los que sobre el pergamino teñido el texto se escribe con tinta de oro o plata. Entre estos se pueden citar algunos sobradamente conocidos como el Génesis Cotton (British Library, Londres, Ms. Cotton Otho B VI), el Génesis de Viena (Österreichische Nationalbibliothek, Viena, Cod. theol. gr. 31) o el Codex Rossanensis (Catedral de Rossano) ${ }^{27}$. El lujo extremo de estos libros hacía de ellos objetos de contemplación que posiblemente se expondrían con carácter ceremonial y litúrgico en espacios ligados a la liturgia cortesana e imperial. Pero los análisis de colorantes

21 A. CARILE, op. cit., 1998, pp. 253-257. Desde el punto de vista iconográfico baste recordar, entre otras imágenes imperiales revestidas de púrpura, los paneles de mosaico de San Vital de Rávena donde Justiniano y Teodora visten sendos mantos purpúreos, o la imagen de Juan II Comneno en Santa Sofía.

22 Los talleres estatales estaban enclavados en distintos lugares del Imperio, pero a partir del s. VII la producción se concentró en la capital, desde donde se controlaba su explotación y comercio. Las sedas purpúreas constituían los regalos de mayor prestigio. Origen constantinopolitano pudieron tener la seda de la cuadriga procedente de la tumba de Carlomagno, conservada en estado fragmentario en el Tesoro de la Catedral de Aquisgrán y en el Musée de Cluny (París), véase A. MUTHESIUS, Byzantine silk weaving. AD 400 to 1200, Viena, 1997, pp. 72-73; A. CARILE, op. cit., 1998, p. 248; y la dalmática de los grifos del museo de la iglesia de Valère, catedral de Sion (Valais), datada en el s. XI, una de las muestras conservadas más tardías de tejido teñido con púrpura de murex, y de la que no hay que descartar que formara parte de los expolios de un botín. Los análisis tintóreos de este tejido han sido realizados por Judith Hofenk de Graff en el Central Research Laboratory de Ámsterdam. Véase Teintures précieuses de la Méditerranée..., op. cit., 1999, cat. 26, p. 104.

23 A. MUTHESIUS, op. cit., 1997, pp. 27 y 28; A. CARILE, op. cit., 1998, pp. 243-253.

24 M. PASTOUREAU, op. cit., 2006, p. 201. En algunos tejidos clasificados como bizantinos se ha detectado el uso de índigo y rubia para obtener el color púrpura, lo que confirma la variedad de recetas y sustancias tintóreas con las que podía obtenerse el color. Véase A. MUTHESIUS, "Essential processes, looms, and technical aspects of the Production of Silk Textiles", A.E. LAIOU (ed.), The Economic History of Byzantium. From the Seventh through the Fifteenth Century, Washington, 2002, pp. 159-160. En los tejidos ricos el murex fue sustituyéndose por el quermes, una sustancia tintórea también muy exclusiva.

25 D. JACOBY, "Silk Economics and Cross-Cultural Artistic Interaction: Byzantium, the Muslim World, and the Christian West", Dumbarton Oaks Papers, 58 (2004) pp. 197-240, manifiesta que tras este acontecimiento no se pudo reunir en Bizancio recursos financieros para la explotación del murex.

26 En un Edicto del año 470, León I proclama que todos los documentos oficiales tenían que estar firmados con púrpura. Véase C.M. BOOKER, op. cit., 1997, pp. 468-469. En este trabajo se realiza un interesante y completo estudio sobre la utilización de la púrpura en los soportes librarios.

27 Ibid., pp. 462-465; I. FURLAN, "Introduzione ai codici purpurei”, O. LONGO (ed.), op. cit., 1998, pp. 317-337. 
realizados a algunos de estos manuscritos han revelado que el color púrpura no se obtenía necesariamente de murex ${ }^{28}$, lo que demuestra que fundamentalmente se daba más importancia, en estos casos, al color que a la sustancia tintórea con que este se obtenía. En el Codex Sinopensis (BnF, París, Ms. Suppl. Grec. 1286) el color púrpura proviene del folium $^{29}$, una planta de origen mediterráneo (chrozophora ticntoria) que debió ser habitual como colorante ya en las primeras obras de este tipo, como más tarde en los códices purpúreos medievales ${ }^{30}$. De hecho, parece probable que en la mayor parte de estos manuscritos se utilizase el folium desde la Antigüedad Tardía, mientras la púrpura de moluscos sería más eventual ${ }^{31}$. También se ha contrastado la utilización de líquenes como la rocella tinctoria y ochrolechia tartárea ${ }^{32}$, como en el caso Codex Purpureus Petropolitanus ${ }^{33}$.

Los manuscritos purpúreos siguieron produciéndose con carácter suntuario y legitimador en el Occidente europeo, como veremos más adelante.

Los objetos purpúreos eran en Bizancio los de valor superior, asociados al poder y con connotaciones imperiales, independientemente de la naturaleza del colorante con el que se obtenía el color, porque lo importante era también la apariencia. Entre los objetos de carácter suntuario teñidos de este color estarían los marfiles purpúreos ${ }^{34}$, como es el caso del Tríptico de la Natividad del Musée du Louvre (inv. OA 5004), de la segunda mitad del s. X, donde se han detectado restos de esta tonalidad en el fondo de las placas obtenido con colorantes de naturaleza vegetal ${ }^{35}$, y en el cofre con emperadores victoriosos a caballo del Tesoro de la Catedral de Troyes, de comienzos del s. XI, donde el fondo purpúreo unido a la iconografía se asocia simbólicamente al triunfo imperial ${ }^{36}$.

Análogo significado imperial a la púrpura tiene el pórfido, término que deriva del

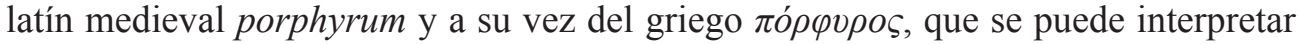
como mármol púrpura. Esta roca magmática, que se extraía en la Antigüedad de las canteras del Mons Porphyrites en el desierto oriental de Egipto, se reservó por sus cualidades -color purpúreo y resistencia- al uso imperial para la realización de re-

28 A. LEPSCHY, "Il colore della porpora”, O. LONGO (ed.), op. cit., 1998, p. 54, apunta que de los residuos del colorante se formaba una harina fósil - creta argentaria - que se utilizaba para teñir los pergaminos. La creta argentaria también se empleaba como pigmento en las pinturas parietales. Véase M. SALVADORI, "La porpora nella pittura parietale romana", O. LONGO (ed.), op. cit., 1998, p. 205.

29 Los análisis se hicieron mediante cromatografía en fase gaseosa y espectrometría de masa en el Centre de Recherches sur la Conservation des Documents Graphiques del CNRS. Véase Teintures précieuses de la Méditerranée..., op. cit., 1999, pp. 110-111.

30 S. KROUSTALLIS, "Quomodo decoretur pictura librorum: materiales y técnicas de la iluminación medieval", Anuario de Estudios Medievales, $41 / 2$ (2011), p. 789.

31 Cfr. nota 28.

32 S. KROUSTALLIS, op. cit., 2011, p. 786, n. 67.

33 Byzantium and Islam, catálogo de la exposición (The Metropolitan Museum of Art, 2012), Nueva York, 2012, cat. 21, pp. 40-41.

34 Sobre la teoría del color en los marfiles bizantinos, véase C.L. CONNOR, The color of ivory. Polychromy on byzantine ivories, Princeton, 1998. Sus hipótesis son rebatidas por A. Cutler (http://www.caareviews.org/ reviews/274, acceso 13/5/2014).

35 The Glory of Byzantium. Art and Culture of de Middle Byzantine Era. A.D. 843-1261, catálogo de la exposición (The Metropolitan Museum of Art, 1997), Nueva York, 1997, cat. 98, pp. 152-153.

36 I. FURLAN, op. cit., 1998, fig. 10, pp. 336-337. 
tratos, columnas monumentales y sarcófagos desde la época de la Tetrarquía ${ }^{37}$. Por tanto, como la púrpura, fue un instrumento de poder. Pero en Bizancio fue invertido su uso y de constituir la última morada del emperador, pasó a revestir por completo la conocida como cámara porphyra, estancia del palacio donde las emperatrices daban a luz al heredero imperial. Los emperadores bizantinos conocidos como porfirogé-

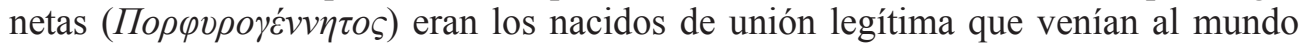
en esta cámara, revestida de pórfido en sus paredes y suelo y guarnecida de sedas de color púrpura. Cuando nacía el heredero se lo envolvía con vendas y pañales púrpura como símbolo de su destino divino y de legitimación. El título de porfirogéneta está documentado por primera vez en 763 en referencia a León IV, pero no se tienen referencias exactas en cuanto al origen de esta cámara en el palacio imperial ${ }^{38}$.

El pórfido se utilizó en Occidente lo largo de la Edad Media como instrumento de poder eclesiástico y civil. San Isidoro de Sevilla afirmaba que era el mármol imperial por excelencia porque "rojeaba como la púrpura"39.

En la Basílica de San Juan de Letrán, sede pontifical hasta el s. XIV, dieciséis de las columnas de la basílica constantinopolitana son de granito rojo y las ocho columnas de su baptisterio son de pórfido. En la Capilla de San Silvestre había dos sitiales de pórfido en el sentido de la imitatio imperii, en alusión a la donación de Constantino por la que se trasladó al papado la soberanía sobre el Imperio de Occidente. La sedia stercoraria se realizó en este mismo material en el s. XII. Y también se utilizó el pórfido para los sepulcros de Inocencio II y Anastasio IV, subrayando el carácter imperial de los pontífices ${ }^{40}$.

Como símbolo de legitimación, las columnas de pórfido de la Capilla Palatina de Aquisgrán fueron mandadas llevar hasta allí por Carlomagno desde Roma y Rávena. Y, según la tradición, León III lo coronó como emperador sobre una lápida circular de este material conservada en el actual pavimento renacentista a la entrada de la basílica vaticana.

También son de pórfido algunas de las columnas de la fachada de la Basílica de San Marcos de Venecia, provenientes del saqueo de Constantinopla en 1204, al igual que el grupo de los Tetrarcas. Y en el interior de la basílica, el ambón meridional del transepto ${ }^{41}$.

En la corte normanda de Sicilia su uso está documentado en la Capilla Palatina de Palermo y en las catedrales de Palermo y Monreale. Y fueron enterrados en bañeras de pórfido reutilizadas algunos de los monarcas como Guillermo I, Guillermo II y

37 Baste recordar, entre otras obras, los Tetrarcas de la plaza de San Marcos en Venecia, la columna de Constantino en Bizancio y el sarcófago de Constantino o de su madre Santa Elena y el de Constanza, la hija del emperador, ambos en los Museos Vaticanos.

38 J. HERRIN, Women in purple. Rulers of medieval Byzantium, Londres, 2001, p. 65. Por otra parte, el último emperador enterrado en un sarcófago de pórfido fue Marciano, que reinó en la parte oriental del Imperio entre 450-457.

39 Etimologías, XVI, 5, 5.

40 A. PARAVICINI BAGLIANI, Le chiavi e la tiara. Immagini e simboli del papato medievale, Roma, 2005, pp. 67-70, y "Los lugares de poder de los Papas (siglos XI-XIII)", E. CASTELNUOVO y G. SERGI (eds.), Arte e historia en la Edad Media I. Tiempos, espacios, instituciones, Madrid, 2009, p. 420.

41 G. LORENZONI, op. cit., 1998, pp. 303-316. 
Federico $\mathrm{II}^{42}$. El uso de estas piezas legitimadas por su antigüedad estaban destinadas a fortalecer la imagen del rey, por eso la reutilización está documentada desde el Bajo Imperio y en la época altomedieval para los emperadores carolingios y otonianos.

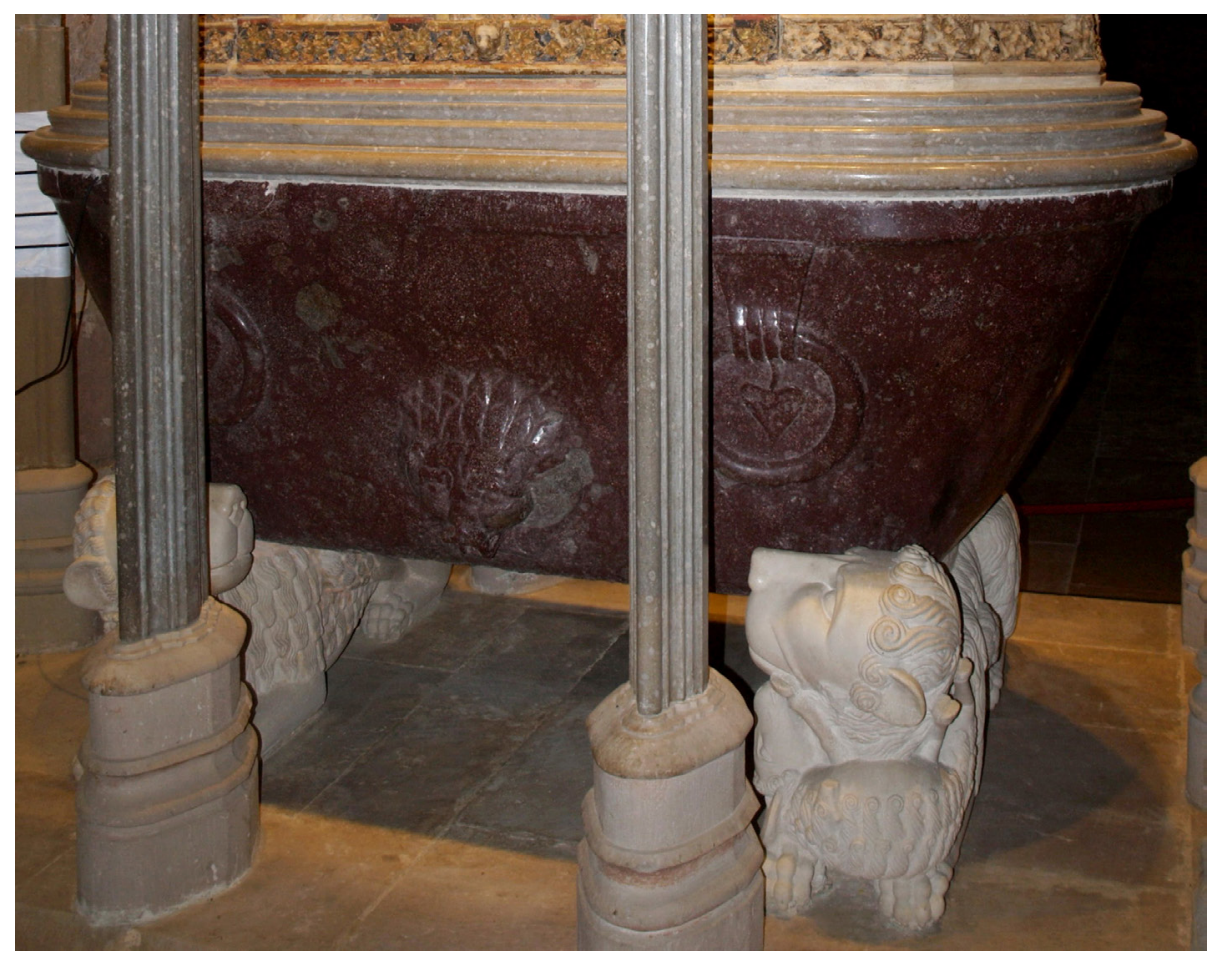

Fig. 1. Urna de pórfido del sepulcro de Pedro III de Aragón (†1285). Monasterio de Santes Creus, Tarragona.

Asimismo es reutilizada la urna del sepulcro de Pedro III de Aragón del Monasterio de Santes Creus en Tarragona ${ }^{43}$ (Fig. 1). Ya antes que el rey, su madre Violante de Hungría fue enterrada en un austero sepulcro con urna de piedra rojiza (Monasterio de Santa María de Vallbona de les Monges, Lérida) quizás con carácter simbólico por el origen de la reina ${ }^{44}$, mientras que el monarca, que ordenó explícitamente que su cadáver se dispusiese en dicha urna, legitimaba de este modo la legalidad y sacralidad de su reinado que estaba en entredicho ${ }^{45}$.

42 Ibid., pp. 302-303.

43 Según la tradición la trajo Roger de Lauria de Sicilia, pero Schlunk afirma que procedía del cercano mausoleo de Centcelles, cfr. ibid., 1998, p. 303.

44 Violante de Hungría, casada con Jaime I el Conquistador, era hija del rey Andrés de Hungría, que ostentaba entre otros títulos el de emperador de Constantinopla tras su participación en la Quinta Cruzada. Quizás por su ascendencia se eligió el color purpúreo para su enterramiento.

45 Por su matrimonio con Constanza de Hohenstaufen, hija de Manfredo I de Sicilia, fue coronado rey de Sicilia en Palermo en 1282 tras el suceso de las Vísperas Sicilianas, que supuso una gran matanza de franceses 


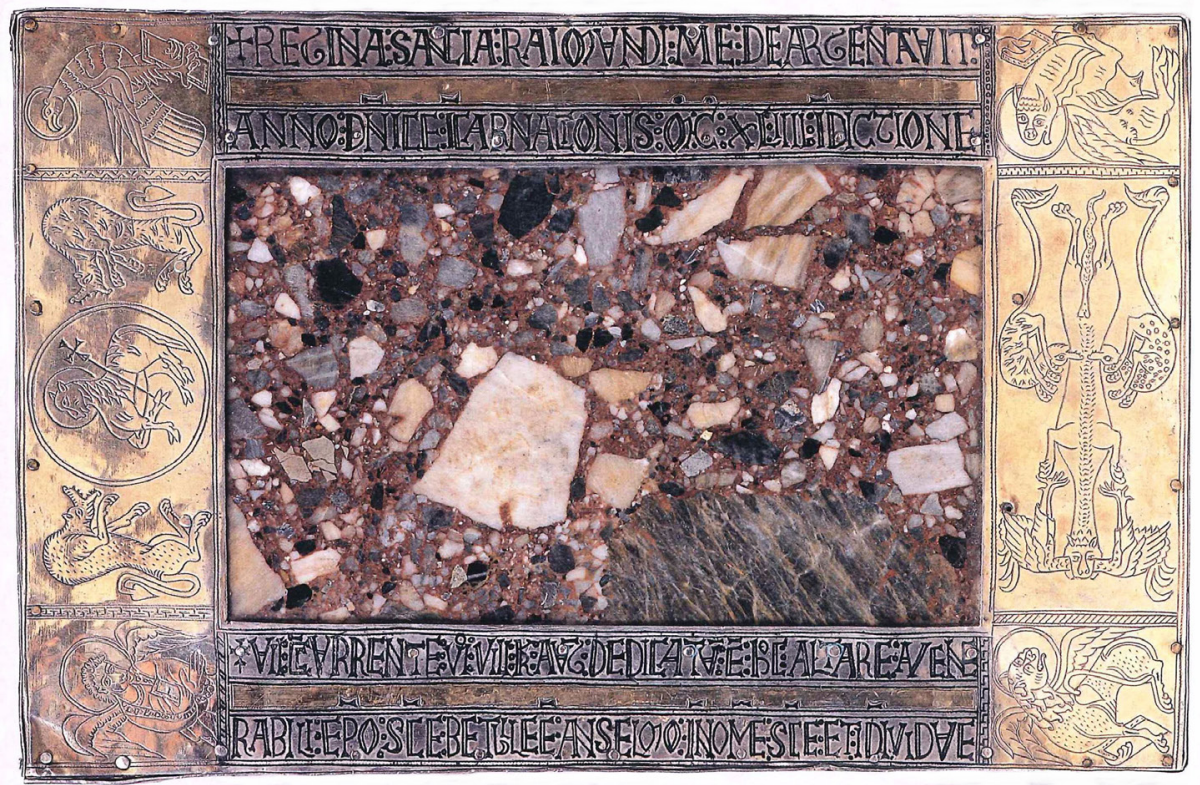

Fig. 2. Ara portátil donada por la infanta Sancha Raimúndez, 1144. Real Colegiata de San Isidoro de León.

Entre los objetos litúrgicos hay piezas que utilizan el pórfido o materiales similares con carácter simbólico. Una de las obras más significativas es el jarrón del águila (Musée du Louvre, París, inv. MR 422) que mandó montar con plata dorada el abad Suger (ca. 1130-1140) aprovechando para el cuerpo un recipiente antiguo de pórfido con el que se crea una imagen con un simbolismo regio y glorificante tanto por el material de la vasija como por la iconografía adoptada tras el montaje, teniendo en cuenta que el destino de la pieza era el tesoro de la abadía de Saint Denis dedicándose al servicio de altar ${ }^{46}$. Por nuestra parte pensamos que en el ara portátil de San Isidoro de León (1144), de mármol rojo y plata nielada en los bordes ${ }^{47}$, donada por la infanta Sancha Raimúndez, la elección de la piedra purpúrea pudo responder a la afirmación de su condición regia (Fig. 2).

Tras la conquista de Tiro por los musulmanes en 640 d.C., las factorías de púrpura se redujeron en el Mediterráneo oriental y la actividad cesó o disminuyó en gran medida en el Mediterráneo occidental ${ }^{48}$. Los musulmanes mostraron un aparente desinterés en el empleo de este tinte, sustituyéndolo por otros colorantes igualmente

a las órdenes de Carlos de Anjou, pretendiente al trono siciliano.

46 P. LASKO, Arte sacro. 800-1200, Madrid, 1999, pp. 386-387.

47 I. BANGO TORVISO (dir.), Maravillas de la España medieval. Tesoro sagrado y monarquía, León, 2000 , cat. 126 .

48 Según Michel Pastoureau, las recetas del púrpura se perdieron a partir de los siglos VIII-IX tanto en Occidente como en Oriente, de modo que el púrpura en la Edad Media nada tenía que ver con el de la Antigüedad (véase M. PASTOUREAU, op. cit., 2006, p. 201, nota 26). 
suntuarios como el quermes (del árabe qirmiz) y el índigo, que tomaron el relevo al múrice ${ }^{49}$. Pero a pesar de no haberse detectado su empleo en las manufacturas textiles, continuaron con su explotación y sobre todo con su comercio por todo el Mediterráneo durante buena parte de la Edad Media ${ }^{50}$.

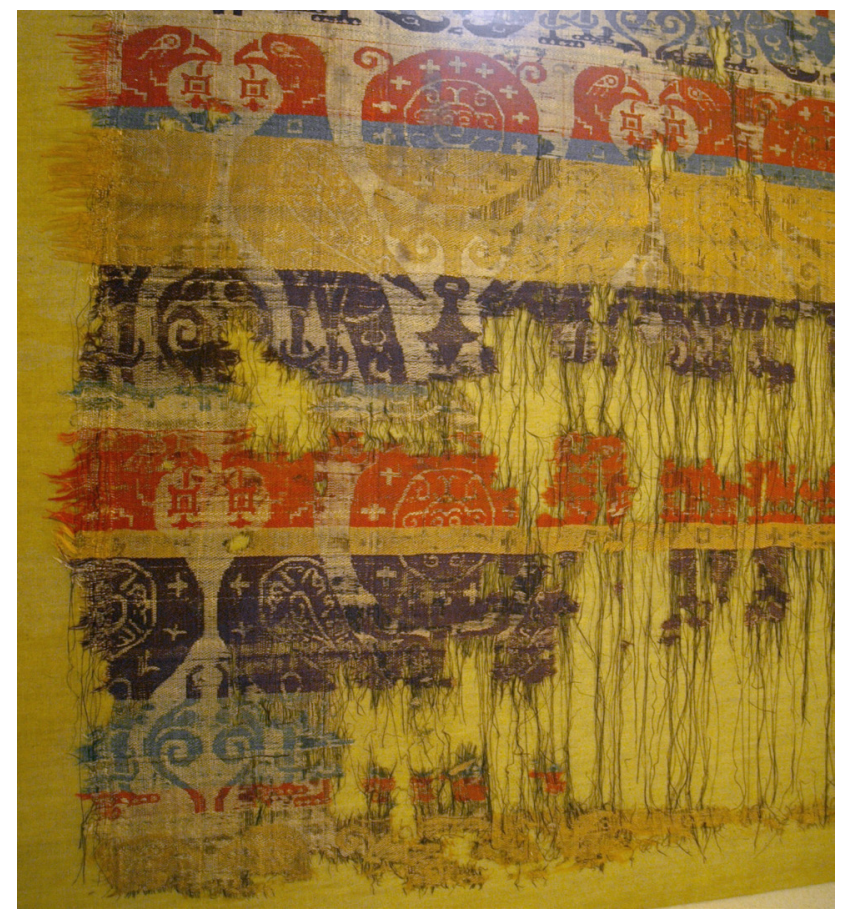

Fig. 3. Fragmento de tejido islámico, siglos XII-XIII. Musées Royaux d'Art et d'Histoire, Bruselas, inv. 1S.Tx.374.

49 En los tejidos hispanomusulmanes analizados en los proyectos que hemos desarrollado estos tintes son habituales, como puede comprobarse en B. GARCÍA GÓMEZ y E. PARRA CREGO, "Tablas de resultados de análisis de los tejidos estudiados", L. RODRÍGUEZ PEINADO y A. CABRERA LAFUENTE (eds.), La investigación textil y los nuevos métodos de estudio, Madrid, 2014, pp. 202-211.

50 En Sicilia la industria continuó en época islámica y se mantuvo en el periodo normando. Según D. JACOBY, op. cit. (2004), en Egipto la producción de púrpura está atestiguada entre los siglos X y XIII. O. REMIE CONSTABLE, Trade and traders in Muslim Spain. The commercial realignment of the Iberian Peninsula 900-1500, Cambridge, 1994, p. 160 recoge las noticias del envío de balas de lana purpúrea desde Alejandría a al-Andalus. Por su parte, el geógrafo Ibn Hawqal en su obra Configuración del mundo (948) habla de la exportación de dibāy (brocados de púrpura) en al-Andalus, véase J. VALLVÉ BERMEJO, "La industria en al-Andalus", Al-Qantara, I, 1-2 (1980), pp. 223-224. En la obra de M. SHATZMILLER, Labour in the medieval islamic World, Leiden, 1994, pp. 103 y 119 se registran términos específicos para los fabricantes y tintoreros de púrpura, como șāni 'al-urdjuwān (fabricante de púrpura) o ardjawānī (tintorero de púrpura). C.R. DODWELL, Anglo-Saxon art: a new perspective, Nueva York, 1982, p. 37, nota 131, menciona cómo tras la conquista musulmana la púrpura siguió exportándose al Oeste, donde se vendía desde los mercados venecianos y amalfinatos (A. CARILE, op. cit., 1998, p. 247). Todas estas noticias no hacen más que revelar la supervivencia de esta industria, lo que plantea la necesidad de la realización de un estudio sobre el papel de la púrpura en el periodo islámico medieval, así como a qué responde realmente la expresión de este término. 
Cabe destacar por su singularidad en la utilización del color púrpura violáceo en su policromía algunos tejidos clasificados como andalusíes ${ }^{51}$, como el conservado en dos fragmentos, uno en los Musei Civici de Venecia (inv. Ce. XXIII n. 491/16) y el otro en los Musées Royaux d'Art et d'Histoire de Bruselas (inv. 1S.Tx.374), fechado en los siglos XII-XIII ${ }^{52}$, donde los motivos decorativos dispuestos en bandas horizontales y formados por aves afrontadas y adosadas a palmetas combinan los colores amarillo, rojo, azul, verde y el mencionado púrpura (Fig. 3). Al igual que el clasificado como almorávide de tradición persa y fechado en el s. XII conservado en el Instituto Valencia de Don Juan de Madrid (inv. 2058) con gacelas afrontadas al árbol de la vida que alternan con aves afrontadas de cabeza vuelta y menor tamaño en una composición en hilera donde los motivos en tonos marfil, amarillo y azul, destacan sobre un fondo purpúreo ${ }^{53}$. En los análisis de color realizados en este tejido se ha identificado como colorante el liquen orceilla-rocella tinctoria-, ya empleado en Roma como sustituto del púrpura para conseguir colores violáceos ${ }^{54}$. Aunque se piensa que este colorante dejó de usarse tras la caída del Imperio Romano y no se volvió a recuperar hasta 1300 en Italia, en los análisis realizados a tejidos islámicos se da en piezas que podrían tener una procedencia oriental ${ }^{55}$.

Por otra parte, el color azul índigo del fondo del pergamino de los manuscritos de Qur'an que se han vinculado a un patronazgo cortesano sugiere la sustitución del púrpura por otros colorantes, como el índigo, ya muy valorado en la Antigüedad como lo fue entre los musulmanes y en la Europa Occidental durante toda la Edad Media ${ }^{56}$,

51 E. FERNÁNDEZ GONZÁLEZ, "El artesano medieval y la iconografía en los siglos del Románico: la actividad textil”, Medievalismo, 6 (1996), p. 72, nota 23, incluye el término tirāzi púrpura en la crónica que Ibn Hayyán de Córdoba hace sobre los regalos con los que los califas obsequiaban a sus súbditos. Igualmente, del mismo autor recoge cómo en el año 942 llegaron a Córdoba comerciantes amalfitanos llevando, entre otros productos, púrpura (ibid., p. 74, nota 28).

52 I. ERRERA, Musées Royaux du Cinquantenaire. Catalogue d'étoffes anciennes et modernes, Bruselas, 1927, p. 21, defiende su procedencia hispana aunque por su delicadeza se identificó con manufacturas iraníes, fatimíes y bizantinas.

53 C. PARTEARROYO LACABA, "Estudio histórico-artístico de los tejidos de al-Andalus y afines", Bienes Culturales, 5 (2005), p. 52, fig. 3. En este mismo número estudia sus ligamentos P. BORREGO DÍAZ, "Análisis técnico del ligamento en los tejidos hispanoárabes", pp. 88-89; los colorantes M.D. GAYO GARCÍA y A. ARTEAGA, "Análisis de colorantes de un grupo de tejidos hispanomusulmanes”, tabla 6, p. 130; y presenta la síntesis de los resultados de su estudio B. CULUBRET WORMS, "Catálogo de los tejidos hispanomusulmanes estudiados", p. 149.

54 D. CARDON, op. cit., 2003, pp. 385-389. En algunos de los tejidos denominados coptos también se ha detectado este tinte (véase, por ejemplo, A. CABRERA LAFUENTE, Tejidos y alfombras del Museo de la Alhambra, Granada, 1997, nº 8, pp. 46-47).

55 Véase, por ejemplo, M.D. GAYO GARCÍA y A. ARTEAGA, op. cit., 2005, tabla 14, p. 134; D. CARDON, op. cit., 2003, p. 388 comenta su uso en emplazamientos vikingos y anglosajones en los siglos IX y $\mathrm{X}$. Se ha detectado su uso en dos tejidos de posible procedencia egipcia clasificados en torno a los siglos VIIIIX del Museo de la Alambra (A. CABRERA LAFUENTE, op. cit., 1997, nº 11, pp. 62-63 y nº 13, pp. 66-67).

56 La indigotina, presente en el índigo y el pastel, es la sustancia tintórea más habitual en los azules de los tejidos hispanomusulmanes analizados en los proyectos que hemos desarrollado. Véase B. GARCÍA GÓMEZ y E. PARRA CREGO, op. cit., 2014, pp. 202-211. La relación entre el índigo y la púrpura es muy próxima y solo varían en algunas moléculas (P. BALL, op. cit., 2004, pp. 253-254). 
ya que parecen claras las conexiones entre esta producción de lujo y los códices purpúreos bizantinos ${ }^{57}$.

La caída del Imperio en Occidente supuso el declive de las factorías extractivas de murex, lo que constituyó una de las causas principales de la disminución y posterior desaparición progresiva de su producción en la Europa occidental ${ }^{58}$. Pero en Occidente la acepción del término púrpura siguió asociándose al poder en cuanto a su majestad, soberanía, justicia y generosidad, virtudes que tenían que adornar al soberano. No tanto el tinte, que dejó de usarse progresivamente siendo sustituido por otros igualmente exclusivos, sino el color como signo de identidad, rango y dignidad, de forma que cumplió, como dice Pastoureau, una función taxonómica ${ }^{59}$, porque el púrpura pasó de prestigioso tinte a prestigioso color, identificándose a comienzos de la Edad Media con la luz y los tonos rojizos ${ }^{60}$, asociado a la panoplia de la Iglesia y el Imperio y, por tanto, signo de distinción. Como en la Antigüedad, el color púrpura atendía a un amplio rango de tonos del marrón, azules plomizos, violetas y rojos, valorándose por su resplandor, luz y brillo ${ }^{61}$, de modo que el concepto púrpura no atendía a un color determinado y estuvo ligado más a la coloración obtenida a partir de costosos tintes. Se mantuvo el vocablo y su valor simbólico pero varió sustancialmente el color con el que el se identificaba, así como las sustancias tintóreas de las que se extraía. Como apunta Ball, la asociación al extinto Imperio dio valor al término desvinculándolo incluso del tinte y del color ${ }^{62}$. En este sentido, hay que tener en cuenta que la expresión adquirió un simbolismo eidético, por lo que no siempre se pueden interpretar literalmente las descripciones ideológicas ${ }^{63}$.

En la Edad Media el término púrpura también tenía otros significados, y de tinte precioso extraído del murex, acabó asociándose a un determinado tipo de tejido, sin tener en cuenta su color ${ }^{64}$. Según Dodwell, el término purpura en latín medieval hacía referencia a una variedad de tela de seda gruesa, llamativa y cara que podía ser de cualquier color, entre los que estaban el púrpura violáceo y el rojo oscuro, uno

57 Byzantium and Islam, op. cit., 2012, cat. 192 A, B, pp. 275-276. Aunque no se conoce el lugar de producción de estos manuscritos se ha propuesto Qairawan en la primera mitad del s. X, sin descartar la corte omeya cordobesa por su relación con los fondos de los mosaicos del mihrab de la aljama, o Sicilia.

58 A pesar de su declive, como han mostrado las excavaciones arqueológicas realizadas en las factorías de Toulon, en el sur de Francia, después del s. V se siguió explotando la producción de púrpura, al igual que en las costas del Atlántico norte, donde al menos en el s. VII, como menciona Beda el Venerable, se hacía extracción de moluscos purpúreos - purpura lapillos- para obtener el preciado tinte en un monasterio de la isla irlandesa de Inishkea. Véase C.P. BIGGAM, "Knowledge of whelk dyes and pigments in Anglo-Saxon England", Anglo-Saxon England, 35 (2006), pp. 23-35.

59 M. PASTOUREAU, op. cit., 2006, p. 142.

60 J. GAGE, op. cit., 1999, pp. 72-73, cita a este respecto a Rabano Mauro, que hace derivar la palabra purpura de puritate lucis y al Anónimo Bernensis (finales del s. XI), que compara el tono rojo obtenido en la preparación del temple de huevo con la más apreciada púrpura.

61 C.R. DODWELL, op. cit., 1982, p. 146.

62 P. BALL, op. cit., 2004, p. 253.

63 M. PASTOUREAU, op. cit., 2006, p. 130.

64 Ibid., p. 143 manifiesta que el ojo medieval estaba acostumbrado a evaluar y distinguir la calidad de los materiales. 
de los más preciados por su brillantez y la luz que reflejaba ${ }^{65}$; esta misma hipótesis la recoge Alfau de Solalinde ${ }^{66}$, sin embargo, Pastoureau considera que calificaba un tejido de bajo precio ${ }^{67}$. Lo cierto es que en torno a los siglos XI-XIII se extiende el significado que identifica púrpura y tejido, como recoge la definición que se da en la General Estoria que describe el término como "porpora otrossi todos saben que es panno de seda, e a esste nombre dun marisco en cuya sangre la tinnen, a que dizen otrossi porpola" 68 .

Desde el s. XIII también fue uno de los siete colores heráldicos, aunque poco usado hasta el s. XVII en escudos reales y reservado en estos primeros tiempos a los de personajes exóticos ${ }^{69}$.

El tinte púrpura extraído de los múrices fue reemplazado por otros de gran valor como el quermes (kermes vermilio $)^{70}$, que resulta de secar al insecto hembra del coccus illicis, parásito que habita sobre robles y encinas, obteniéndose un color rojo de gran intensidad ${ }^{71}$. Pero el púrpura también se identificaba con el azul obtenido del índigo (indigofera tinctoria), tinte de naturaleza vegetal que se extrae de las flores del arbusto de su nombre y que tuvo origen posiblemente en la India ${ }^{72}$; de hecho, a partir del s. XII, la "púrpura real" se identificó con los tonos azulados porque el color azul fue cada vez más usado por la aristocracia, pasando a ser un color principesco y $\mathrm{real}^{73}$. En las descripciones donde se cita el color púrpura no se mencionan sus tonos,

65 C.R. DODWELL, op. cit., 1982, pp. 146-147, define estas telas como shot-silk taffeta, un tafetán grueso de seda.

66 J. ALFAU DE SOLALINDE, Manual de tejidos españoles o nomenclatura de los tejidos españoles del siglo XIII, Madrid, 1981, p. 149.

67 M. PASTOUREAU, op. cit., 2006, p. 201, nota 26, alude al purpura bise, tejido de calidad inferior de colores grisáceos, marronáceos o crudos. Ya en Bizancio el término blattion significaba no solo púrpura, sino por extensión tejido de seda o lana teñido de púrpura no de la mayor calidad por usarse para la tinción jugo de múrice - porphyra talassiné-, coccus ilicis o la agalla del coccus tinctorius, que en Italia reemplazó en la industria de la púrpura al extracto del murex. Véase A. CARILE, op. cit., 1998, p. 248.

68 General Estoria, I, 431b53. Según P. BALL, op cit., 2004, p. 257, en España en el s. X el término púrpura se había generalizado como tejido de seda.

69 M. PASTOUREAU, op. cit., 2006, p. 251, nota 30. Hasta los siglos XV-XVI tenía un color más apagado para sustituirse después por un violeta grisáceo coincidiendo con el redescubrimiento de la etimología latina de la palabra, que designaba el color rojo violáceo utilizado por los emperadores romanos.

70 Teintures précieuses de la Méditerranée..., op. cit., 1999, pp. 31-33; D. CARDON, op.cit., 2003, pp. 476-483. El quermes podía sustituirse o mezclarse con la rubia (rubia tinctorum), tinte de origen vegetal mucho más económico y cultivado en toda la Cuenca del Mediterráneo, véase D. CARDON, op. cit., 2003, pp. 101-111.

71 En el Tapiz de la Creación de la Catedral de Gerona el mar purpúreo donde se desarrolla la historia de la invención de la cruz es de color rojo. Véase M. CASTIÑEIRAS, El tapiz de la creación, Gerona, 2011, p. 17. Para el autor, el protagonismo del color púrpura y la representación de Constantino en esta parte del bordado son imágenes al servicio de la idea teocrática del poder (Addendum: notas al Tapiz después de su última restauración, p. 114).

72 La indigofera tinctoria, procedente de la India, era muy costosa y se sustituyó a menudo por el pastel (isatis tinctoria), cultivado en toda Europa y mucho más económico, aunque su color no era tan intenso y resistente (D. CARDON, op. cit., 2003, pp. 274-290).

73 J. GAGE, op. cit., 1999, p. 15; M. PASTOUREAU, op. cit., 2000, dedica un profundo estudio a la historia del color azul en la sociedad medieval; M. PASTOUREAU, op. cit., 2006, pp. 143-144. El azul se convirtió en el color de la realeza divina, adoptándose para la indumentaria de Cristo y de la Virgen. En Francia la dinastía de los Capetos adoptó el color azul para el manto real, mientras en los reinos hispanos los reyes utilizaron los tonos rojo escarlata. 
por lo que teniendo en cuenta que dichas descripciones eran fundamentalmente ideológicas, como se ha indicado más arriba, cabe pensar que cuando se menciona este color se refiere a cualquiera de los resultantes de estos u otros tintes valorados por su gran resistencia a la luz y los brillos que reflejaban.

Para los códices purpúreos, que como en Oriente estuvieron asociados al poder, se mantuvieron los tonos violáceos. Uno de los primeros ejemplos conservados en Occidente es el Codex Argenteus (Uppsala Universitetsbibliotek, Ms. DG 1), evangeliario escrito en lengua goda, con caracteres en oro y plata sobre pergamino color púrpura obtenido con tintes vegetales, posiblemente ejecutado en Rávena a comienzos del s. VI para Teodorico, por lo que emularía esos códices preciosos que el príncipe habría conocido en su juventud pasada en Constantinopla como rehén ${ }^{74}$. Desde el s. VII en los distintos reinos occidentales se produjeron códices de este tipo. San Isidoro los menciona en sus Etimologías cuando habla de los distintos tipos de códices ${ }^{75}$ y también recoge los procedimientos que Plinio describe en su obra para la obtención del color $^{76}$. Pero en la Edad Media, como ocurrió para la tintura de pergaminos purpúreos en Bizancio, la mayoría de los pigmentos utilizados eran mezcla de rojo y azul obtenidos de minerales y sobre todo de vegetales, o bien el ya mencionado folium, colorante que vira de color -rojo, púrpura o azul- según el soporte al que se aplica y cuyo proceso de extracción no era nada simple ${ }^{77}$. De hecho, el citado tinte viene descrito para el teñido de pergaminos en la obra de Teófilo, Schedula diversarum artium, en el Libro dell'arte de Cennino Cennini y en un recetario castellano del s. XV conservado en la Facultad de Medicina de Montpellier ${ }^{78}$.

Según Dodwell ${ }^{79}$, en el s. VII llegaron a Inglaterra códices purpúreos y se produjeron en la isla en el s. VIII, fechándose a mediados de la centuria el Codex Aureus (Kungliga Biblioteket, Estocolmo, Ms. A. 135), realizado probablemente en Canterbury y donde alternan páginas teñidas en púrpura escritas en oro y plata y páginas sin teñir. En estos reinos anglosajones sus príncipes gustaron de utilizar vestimentas purpura guarnecidas con oro y joyas ${ }^{80}$.

En los imperios carolingio y otoniano estos códices constituyeron un signo de distinción asociado a la panoplia de la Iglesia y el estado como símbolo de prestigio y poder. Su patrocinio se entendía como una muestra de prestigio del comitente. En el periodo carolingio los códices purpúreos estuvieron vinculados a la figura imperial como símbolo de continuidad y vinculación con el Imperio Romano; parece que actuaban con un poder taumatúrgico como expresión de la sacralidad del poder. El

74 C.M. BOOKER, op. cit., 1997, pp. 475-476. El vínculo de Teodorico con Bizancio hizo posible que en la corte ostrogoda funcionase uno de los talleres estatales imperiales de púrpura, conocidos como bapheia (A. CARILE, op. cit., 1998, p. 251).

75 "Membrana autem aut candida aut lutea aut purpurea sunt" (Etimologías, VI, 11, 4).

76 Ibid., XVI, 9.

77 B. GUINEAU, "Le Folium des enlumineurs, une couleur aujourd'hui disparue", Archéologie Médiévale, 26 (1996), pp. 23-44.

78 R. CÓRDOBA DE LA LLAVE, "Un recetario técnico castellano del siglo XV: el manuscrito H490 de la Facultad de Medicina de Montpellier", En la España Medieval, 28 (2005), pp. 15-16.

79 C.R. DODWELL, op. cit., 1982, p. 157. Parece que en este siglo el obispo San Wilfredo, originario de Northumberland, comisionó libros purpúreos de los cuales pudo tener conocimiento por su viaje a Roma.

80 Ibid., pp. 180-181. 
Evangeliario de Godescalco (BnF, París, Ms. Nouv. Acq. Lat. 1203) fue encargado por Carlomagno y su esposa Hildegarda (781-783). El Salterio de Dagulfo (Österreichische Nationalbibliothek, Viena, Cod. 1861) constituyó un regalo del emperador al Papa Adriano (783-795). Los Evangelios de la Coronación (Kunsthistorisches Museum, Viena, Schatzkammer, Inv. XIII 18), ca. 800, fueron encontrados por Otón III cuando se abrió la tumba de Carlomagno, que se había enterrado con ellos por su carácter apotropaico, siendo utilizados desde entonces por los emperadores del Sacro Imperio para su coronación. La Biblia Viviana o Primera Biblia de Carlos el Calvo (BnF, París, Ms. Lat. 1) salida del scriptorium de San Martín de Tours, fue un regalo del conde Viviano al emperador. La Biblia de Teodulfo (BnF, París, Ms. Lat. 9380) muestra el valor de los códices purpúreos entre los dignatarios eclesiásticos.

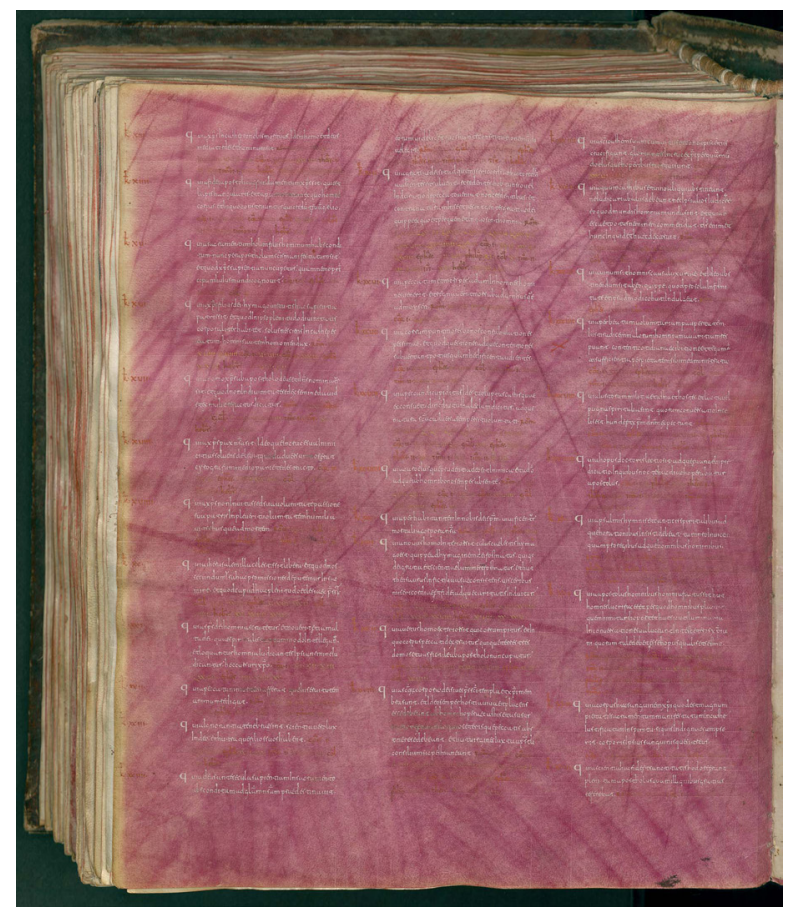

Fig. 4. Codex Biblicus Cavensis, primera década del s. IX (folio 253v). Biblioteca de la Abadía de la Santísima Trinidad de Cava dei Tirreni, Ms. 1.

Los emperadores otonianos redactaban los documentos oficiales más importantes en pergamino púrpura como símbolo de la cultura imperial, igual que en Bizancio, pero también los dignatarios eclesiásticos encargaron códices purpúreos vinculados a la tradición de este tipo de producción para los libros sagrados. El Evangeliario Strahov (Biblioteca Strahov, Praga), ca. 980. fue ejecutado por el maestro del Registrum Gregorii, que trabajó para Egberto de Tréveris, obispo de Colonia, de Tréveris y canciller de Otón II desde 976, que también patrocinó entre 980-993 el Codex Egberti 
(Stadtbibliothek, Tréveris, Ms. 24) realizado posiblemente en Reichenau, aunque tiene algunas miniaturas del maestro del Registrum Gregorii.

En los reinos ibéricos también queda constatado el uso de la púrpura en los manuscritos como símbolo de legitimación y poder. En el scriptorium áulico asturiano en tiempos de Alfonso II pudo realizarse el Codex Biblicus Cavensis en la primera década del s. IX (Biblioteca de la Abadía de la Santísima Trinidad de Cava dei Tirreni, Ms. 1) firmado por el escriba Danila en el folio $166 \mathrm{v}^{81}$. En este códice un folio se tiñe en azul y tres en púrpura (Fig. 4), siguiendo la tradición de los manuscritos de la Antigüedad Tardía y pudiendo ejercer, a su vez, influencia en las biblias carolingias a resultas del intercambio de embajadas entre Alfonso II y Carlomagno.

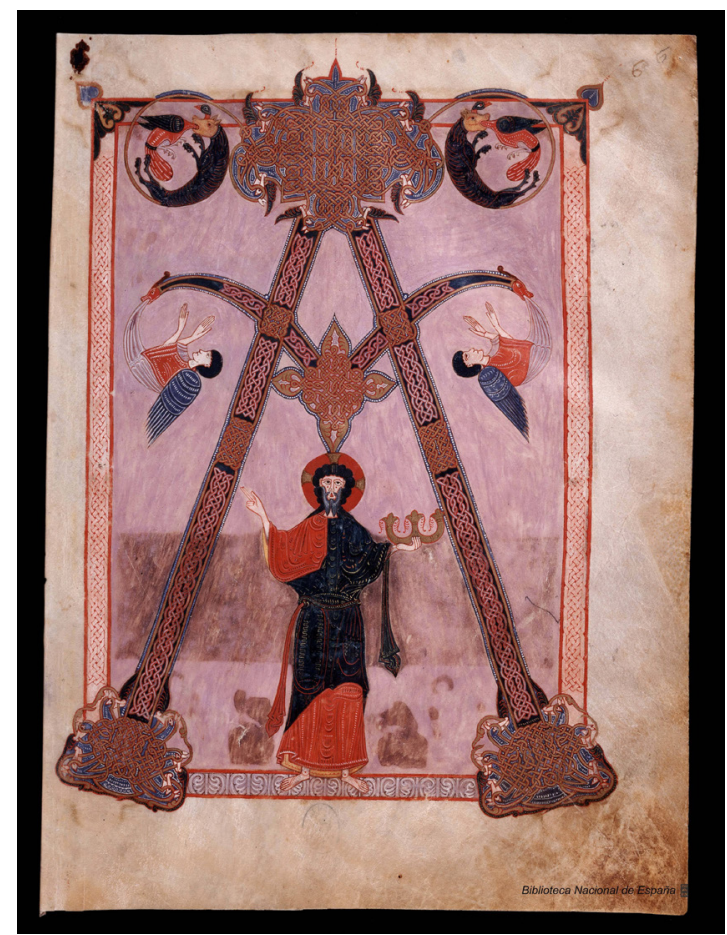

Fig. 5. Beato de Fernando I y Sancha, 1047, Cristo como alfa y omega (folio 6r). BNE, Madrid, Ms. Vit. 14-2.

El color púrpura se utilizó, igualmente, en los códices del reinado de Fernando I, que conectan con los modelos artísticos carolingios y otonianos y tienen como función enfatizar el poder del monarca ${ }^{82}$. En el Beato de Fernando I y Sancha de 1047

81 P. CHERUBINI, J.A. VALDÉS GALlEGO, A. GARCÍA LEAL, La Biblia de Danila (Codex Biblicus Cavensis, Ms. 1 de la abadia de la Santísima Trinidad de Cava dei Tirreni), Gijón, 2010.

82 M.A. CASTIÑEIRAS GONZÁLEZ, “Algunos usos y funciones de la imagen en la miniatura hispánica del siglo XI: Los Libros de Horas de Fernando I y Sancha”, I. CASTRO, M.J. NIETO y V. SERRÃO (coords.), Propaganda e poder. Congresso Penisnsular de História da Arte (Lisboa, 5-8 mayo, 1999), Lisboa, 2001, 
(BNE, Madrid, Ms. Vit. 14-2), en la miniatura inicial (fol. 6r) Cristo está cobijado por la letra Alfa, porta en su mano izquierda la omega y destaca de un fondo morado purpúreo signo del carácter imperial de su promotor (Fig. 5). Del mismo color es el fondo de la banda inferior del folio con la representación de la Cruz y el Cordero adorados por ancianos tañendo instrumentos (fol. 6v). En el Diurnal de Fernando Iy Sancha de 1055 (Biblioteca Xeral Universitaria, Santiago de Compostela, Ms. 609), muestran fondo purpúreo la miniatura con la letra Alfa (fol. 1r) y el folio $207 \mathrm{v}$, donde la escritura con letras doradas destaca sobre el fondo tintado de dicho color ${ }^{83}$ (Fig. 6).

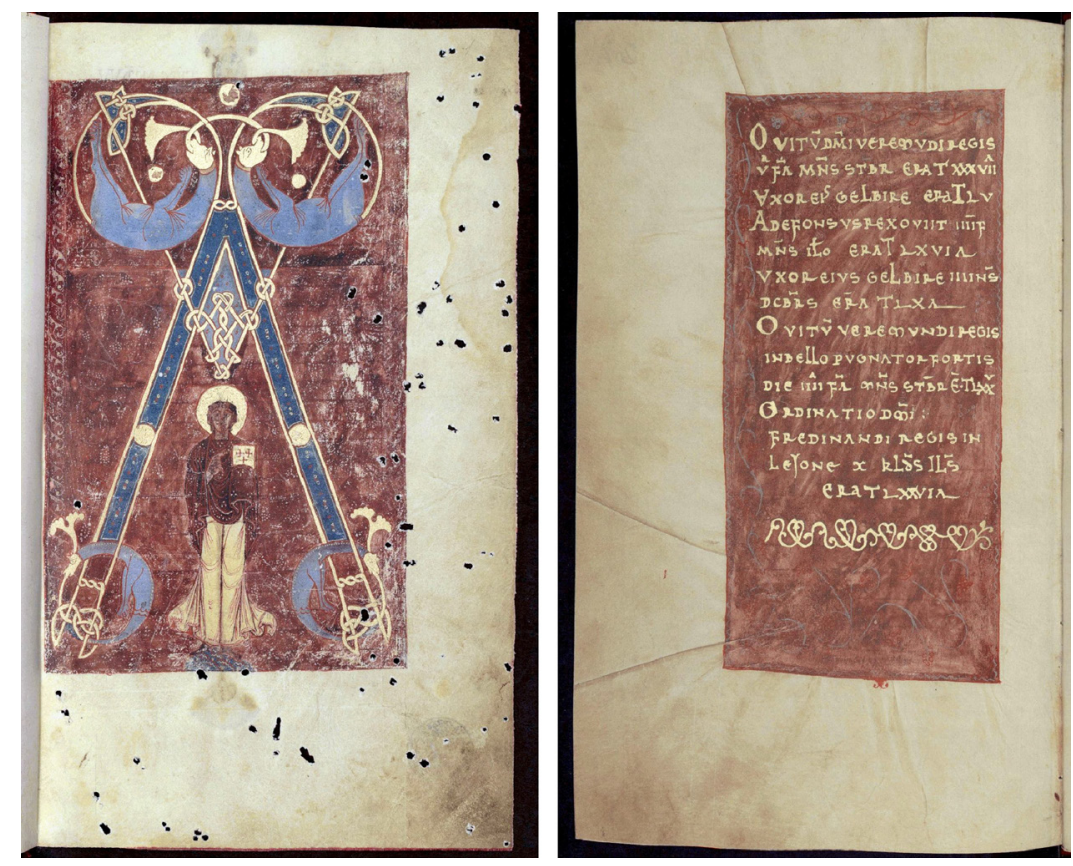

Fig. 6. Diurnal de Fernando I y Sancha, 1055, Alfa (folio 1r) y obituario regio (folio 207v). Biblioteca Xeral Universitaria, Santiago de Compostela, Ms. 609 (Res. 1).

Por su parte, en el Parma Ildefonsus (Biblioteca Palatina, Parma, Ms. 1650) producido en Cluny entre 1090-1100 copiando la obra De Virginate Santae Mariae de San Ildefonso (610-667) y comisionado por el cluniacense arzobispo de Toledo Bernardo de Sédirac (Sauvetat), muchas páginas presentan el fondo púrpura, ya sea para servir de base a los motivos iconográficos o a los textos con letras doradas, sirviendo como modelo para otros manuscritos toledanos ${ }^{84}$.

p. 87 , nota 40 , se cuestiona si la utilización de la púrpura y el oro no habría que ponerlo en relación con el prestigio de la tradición astur-leonesa.

83 J. WILLIAMS, "Fernando I and Alfonso VI as Patrons of the Arts", J. MARTÍNEZ DE AGUIRRE y M. POZA YAGÜE (eds.), Alfonso VI y el arte de su época, vol. extraordinario (2) de Anales de Historia del Arte (2011), p. 414.

84 Ms. 10087 de la Biblioteca Nacional de España, del s. XIII. 
Un interesante códice del que no se ha podido determinar la naturaleza del tinte del fondo violáceo es el VIII Thalamus de Narbona (Archives Municipales, Narbona, Ms. AA 108) fechado ca. 1221. En este manuscrito, los folios con ilustraciones sobre fondo violáceo se disponen en las guardas, anverso con la Crucifixión y reverso con el Salvador y Tetramorfo ${ }^{85}$.

Si en los códices purpúreos dominaban los tonos violáceos, cuando hablamos de la indumentaria regia, en la que el color púrpura era uno de los símbolos más elocuentes asociado al poder, es más difícil determinar los tonos a los que alude el término.

Aunque no se conservan imágenes icónicas policromas de Carlomagno, se conoce el gusto del emperador y de su corte por vestir trajes con motivos púrpura por la asociación del color con la cultura imperial, como signo de continuidad y como uno más de los emblemas de la imitatio imperii. En este sentido, son muy interesantes por su fondo púrpura los fragmentos del tejido de las cuadrigas (Tesoro de la Catedral de Aquisgrán y Musée de Cluny) ${ }^{86}$ procedentes de su enterramiento, porque pudieron formar parte de su ajuar funerario.

Los fluidos contactos de la corte otoniana con Bizancio a partir del matrimonio de Otón II con la princesa bizantina Teofanos implicarían también el uso de indumentaria ceremonial purpúrea, como se aprecia en los retratos arquetípicos de los emperadores. En el retrato de Otón II del Registrum Gregorii (Musée Condé, Chantilly, Ms. 14bis) el emperador entronizado y rodeado por las cuatro provincias del Imperio viste túnica púrpura y manto rojo con flores doradas; del mismo color son las ropas de Otón III en el Evangeliario de Otón III (Bayerische Staatsbibliothek, Munich, Clm 4453), rodeado por los poderes civiles y religiosos, y las de Otón III o Enrique II en su coronación (fol. 59v) según el Apocalipsis de Bamberg (Staatsbibliothek, Bamberg, Ms. A. II. 42).

Del Sacro Imperio se conservan algunas piezas muy significativas ${ }^{87}$ de las que destacamos por su simbolismo el manto de las estrellas (catedral de Bamberg), posiblemente realizado en un taller alemán o de Italia meridional en torno al año 1020 para la coronación del emperador Enrique II. La decoración bordada con un complejo programa iconográfico de estrellas y constelaciones que hay que relacionar con la dimensión cósmica del imperio estaba dispuesta sobre un tejido de seda asargada color violeta oscuro que se cambió en 1503 por un damasco de seda azul de procedencia italiana ${ }^{88}$. El manto de Roger II de Sicilia (Kunsthistorisches Museum, Viena, inv. XIII 14) de color rojo púrpura, realizado en los talleres reales de Palermo en 11331134, dispone sus bordados sobre una seda asargada teñida con quermes. Este manto fue usado posteriormente por los emperadores del Sacro Imperio en la ceremonia de la coronación. Del mismo color son el resto de los accesorios que completaban el conjunto de la indumentaria conservada en el museo vienés: guantes, zapatos y cal-

85 Teintures précieuses de la Méditerranée..., op. cit., 1999, cat. 32, pp. 111-113.

86 Cfr. nota 22.

87 A. CARILE, op. cit., 1998, pp. 247-248.

88 C.R. DODWELL, Artes pictóricas en Occidente. 800-1200, Madrid, 1995, pp. 59-61; K. STANILAND, Bordadores, Madrid, 2000, p. 77, fig. 75; y M. CASTIÑEIRAS, op. cit., 2011, pp. 31-32. 
cetas $^{89}$, así como la dalmática de las águilas, realizada en seda damasquinada china de color rojo púrpura y mencionada por primera vez entre las ropas de la coronación en $1350^{90}$.

El derecho al uso de la púrpura por parte de los emperadores se puso en entredicho en el contexto de las luchas entre el Papado y el Imperio de la segunda mitad del s. XI. Si hasta entonces se reservaba el derecho a vestir la púrpura al emperador, a partir de la difusión del Constitutum Constantini, que afirmaba la superioridad espiritual y temporal del Papa, en la corte pontificia se promocionó la idea de que Constantino había concedido al papa Silvestre I el uso de las insignias imperiales entre las que estaba la clámide púrpura, de modo que el Papa tenía derecho a portar vestiduras purpúreas ${ }^{91}$. Como ratificación de este derecho se realizaron ciclos iconográficos donde se muestra al Papa con las vestiduras acordes a lo estipulado por la donatio en el momento en que se plantean los conflictos con el Imperio ${ }^{92}$. En el Exultet Barberini (Biblioteca Apostólica Vaticana, Cod. Barb. Lat. 592), ca. 1087, creado en la abadía de Montecasino en el contexto de un programa deliberado para producir textos litúrgicos conformes a la liturgia de Roma en el marco de la reforma gregoriana, el manto del emperador y la cappa rubea del Papa son del mismo tono carmesí. En el Oratorio de San Silvestre de la basílica romana de Santi Quattro Coronati (1248), donde se representa un ciclo de la vida legendaria del emperador Constantino según los Actus Silvestri en un momento en el que se plantean conflictos con el emperador Federico II, el Papa y Constantino visten de púrpura violácea, interpretándose como un gesto simbólico de sumisión del emperador al Papa ${ }^{93}$. En la capilla del Sancta Sanctorum del Palacio Papal de Letrán, Nicolás III vestido con la cappa rubea ofrece el modelo de la capilla (1278); y en la decoración al fresco de la loggia lateranense (ca. 1300), Bonifacio VIII luciendo el mismo color bendice al pueblo desde el mismo espacio en un ciclo donde se pretendía subrayar el vínculo que unía al papado con la concesión de Constantino, expresándose de este modo las aspiraciones imperialistas de Bonifacio $^{94}$.

89 R. BAUER, “Il manto di Ruggero II”, M. D’ONOFRIO (ed.), I normanni: popolo d'Europa 1030-1200, Venecia, 1994, pp. 279-287.

90 K. STANILAND, op. cit., 2000, p. 30, fig. 27. La seda de la dalmática está teñida con púrpura real de tonos rojizos.

91 El Constitutum Constantini posiblemente fue redactado entre 750 y 850 por el Papa Esteban II, que puso en el trono a Pipino el Breve. El Papa y los cardenales vestían de púrpura como un símbolo de potestad y dignidad en cuanto partícipes del poder universal otorgado a los sucesores de Pedro, por tanto era símbolo de la Iglesia triunfante. El Concilio de Lyon de 1245 lo estableció canónicamente como color cardenalicio aunque sus tonos variaron a partir del uso del quermes como tinte dando como resultado un color escarlata. En 1566 Pío V cambió el color de la indumentaria papal por el blanco, manteniéndose el calzado púrpura para hacer valer el argumento de la donatio (A. CARILE, op cit., 1998, p. 256). A partir del s. IX el púrpura violáceo formó parte de los colores litúrgicos con un sentido penitencial, como lo reflejan los tratados especulativos de liturgistas como el cardenal Lotario, futuro Inocencio III. Véase M. PASTOUREAU, op. cit., 2006, p. 137; G. FILORAMO, op. cit., 1998, pp. 229-230. Hay que tener en cuenta que los mártires eran purpurei porque dieron su sangre por Cristo.

92 A. PARAVICINI BAGLIANI, op. cit., 2005, p. 65.

93 Ibid., pp. 66-67.

94 G. HOLMES, Florencia, Roma y los orígenes del Renacimiento, Madrid, 1993, p. 133. Únicamente se conserva este fragmento de todo el ciclo constantiniano, relacionándose estas pinturas con las escenas del ciclo 


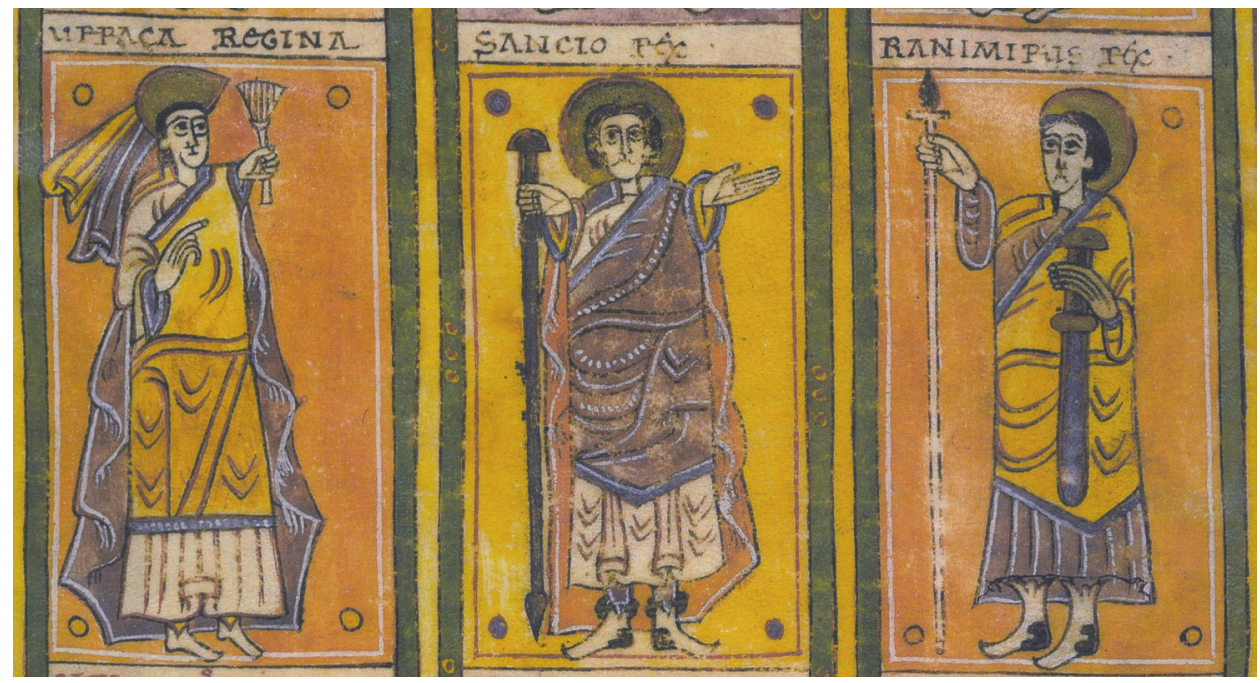

Fig. 7. Codex Albeldensis, 976, Urraca, Sancho y Ramiro (folio 428r). RBME, Ms. D.I.2

Desde los tiempos de la monarquía visigoda el manto de los reyes hispanos también era púrpura como elemento emblemático de su condición regia, heredando de esta forma la costumbre imperial. Isidoro de Sevilla afirma que "los reyes ostentan la insigne vestidura de la púrpura como símbolo de la dignidad regia" "También informa el santo hispalense que Leovigildo fue el primero que se presentó entre los suyos cubierto de la vestidura real ${ }^{96}$. Esta costumbre continuaría a lo largo de la Alta Edad Media entre los reyes hispanos, como se confirma iconográficamente, por ejemplo, en los retratos arquetípicos del Codex Albeldensis o Vigilanus fechado en 976 (RBME, Ms. D.I.2), donde los reyes visten con púrpura (Fig. 7), mismo color que viste Fernando I en el ya mencionado Diurnal en la imagen donde se le representa con la reina recibiendo el códice de manos de su autor (fol. 3v) ${ }^{97}$ (Fig. 8). Los mismos tonos púrpura violáceos se mantuvieron a lo largo de los siglos, como se desprende de la imagen de Fernando III (fol. 12r) de las Cantigas de Santa María (Biblioteca Nazionale Centrale, Florencia, Ms. B.R.20) ${ }^{98}$; o de los guantes de punto de seda morada y oro que luciría la difunta Beatriz de Suabia, madre del Rey Sabio, en su sepultura de la Catedral de Sevilla ${ }^{99}$.

superior de Asís donde el Papa aprueba la Regla franciscana.

95 Etimologías, VII, 2, 2. También el santo hispalense dice que era en Tiro donde se realizaba la mejor púrpura todavía en su época $(\mathrm{XV}, 1,27)$.

96 I.G. BANGO TORVISO, "Hunctus rex. El imaginario de la unción de los reyes en la España de los siglos VI al IX”, CUPAUAM, 37-38 (2011-2012), pp. 750-751.

97 J. WILLIAMS, op. cit., 2011, p. 416.

98 Véase en este mismo volumen L. MOLINA LÓPEZ, "El ajuar funerario de Beatriz de Suabia: elementos para una propuesta iconográfica del simulacro de la reina en la Capilla de los Reyes de la Catedral de Sevilla", fig. 2a. También se representa con manto púrpura violáceo en el Libro de Ajedrez, Dados e Tablas (RBME, Ms. T-I-6), fol. 7r.

99 Ibid., p. 382 , nota 46. 


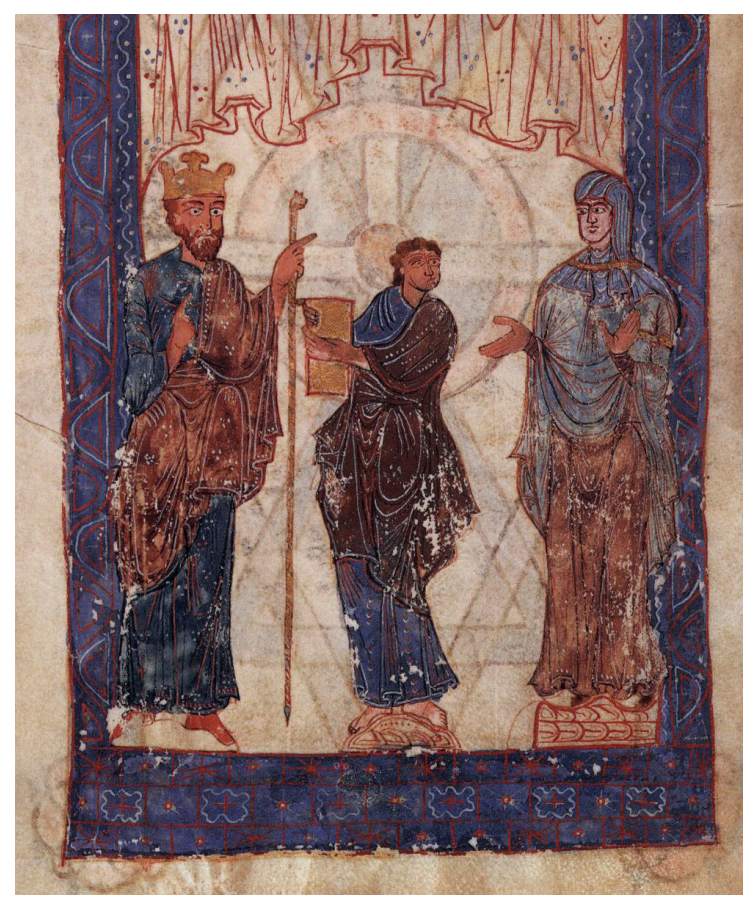

Fig. 8. Diurnal de Fernando I y Sancha, 1055, los reyes recibiendo el códice de manos de su autor (folio 3v). Biblioteca Xeral Universitaria, Santiago de Compostela, Ms. 609 (Res. 1).

Sin embargo, como ya hemos mencionado, el rojo quermes citado en la documentación como grana o escarlata adquirió en la Baja Edad Media el rango que en tiempos pasados había tenido el tinte púrpura, sustituyéndolo por tanto simbólicamente. Las ricas telas al servicio de las clases privilegiadas a menudo se teñían con el coccus que proporcionaba un brillante color escarlata, como es el caso de las tibalias de Rodrigo Ximénez de Rada (Abadía de Santa María de Huerta, Soria) ${ }^{100}$, y su utilización abusiva llevó a que se dictaran en Castilla en el s. XIII leyes suntuarias restringiendo su uso al rey ${ }^{101}$. Dentro de este gusto en la indumentaria real cabe destacar el pellote de Enrique I (Monasterio de Santa María la Real de Huelgas, Burgos), de seda color escarlata tintado con quermes ${ }^{102}$.

En los mantos reales armoriados, que se convierten en soportes heráldicos con gran valor emblemático y simbólico, el carmesí jugó un papel fundamental. El manto

100 Vestiduras Ricas. El Monasterio de las Huelgas y su época 1170-1340, Madrid, 2005, cat. 33, pp. 198-199.

101 J. GAGE, op. cit., 1999, p. 111, considera al color escarlata sucesor natural del color púrpura y afirma que en el s. XV adquiere en España el mismo significado que purpura. Las Cortes de Valladolid de 1258 prohibieron el uso de calzas escarlata a escribas, ballesteros, halconeros, porteros y escuderos y dispusieron que solo el rey podía llevar capa aguadera de escarlata (A. DESCALZO, "El vestido entre 1170 y 1340 en el Panteón Real de las Huelgas", Vestiduras Ricas..., op. cit., 2005, p. 109).

102 Vestiduras Ricas..., op. cit., 2005, cat. 9, p. 156. 
cuartelado de Fernando III con el que fue enterrado en la Catedral de Sevilla (Armería del Palacio Real, Madrid) se decora con castillos dorados sobre fondo rojo y leones rojos sobre fondo blanco ${ }^{103}$, igual que la capa pluvial atribuida a Don Sancho de Aragón (Catedral de Toledo), donde los castillos y leones se combinan en una red octogonal con las barras de Aragón y el águila del Imperio, lo que ha permitido establecer que el tejido pudo pertenecer a un manto regio de Alfonso $\mathrm{X}^{104}$, el cual se representa en las Cantigas y el Libro de Ajedrez con vestido similar ${ }^{105}$.

En la documentación no se distinguen los tintes utilizados, primando la idea del púrpura independientemente de la coloración que se le otorgase. Así, cuando Juan I de Castilla nombró heredero a su hijo Enrique en 1388, le hizo entrega entre otros emblemas de dignidad de un manto púrpura ${ }^{106}$; y cuando Fernando el Católico hizo su entrada triunfal en Nápoles en 1505, vestía un manto de terciopelo carmesí1 ${ }^{107}$. En ambos casos el color púrpura, independientemente de su tonalidad, adquiere un significado de poder regio.

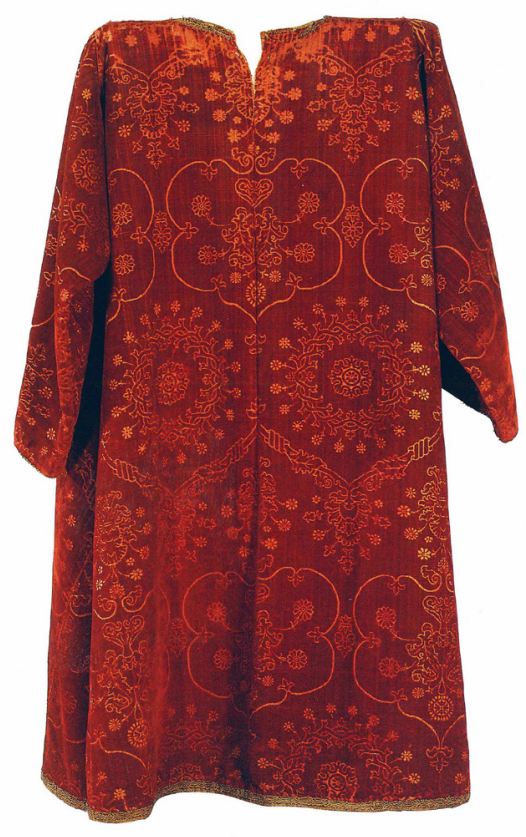

Fig. 9. Marlota de Boabdil, s. XV. Museo del Ejército, Toledo, inv. 24702.

103 Ibid., fig. 41, p. 93.

104 E. MORRAL I ROMEU y A. SEGURA I MAS, La seda en España. Leyenda, poder y realidad, Barcelona, 1991, pp. 68-69.

105 Por ejemplo, en la miniatura donde el rey se representa junto a sus colaboradores del escritorio real en el Libro de los Juegos, fol. 47r. (RBME).

106 S.M. CORONAS GONZÁLEZ, "Evolución institucional del Principado de Asturias", B. AGUILERA BARCHET (ed.), La figura del príncipe de Asturias en la Corona de España, Madrid, 1998, p. 72.

107 J. DE CONTRERAS, MARQUÉS DE LOZOYA, Los orígenes del Imperio: La España de Fernando e Isabel, Madrid, 1939, p. 73. 
De terciopelo carmesí muy intenso es la marlota - malluta- de Boabdil (Museo del Ejército, Toledo, inv. 24702) (Fig. 9), color de la dinastía de los Banu Ahmad que además adquiere todas las connotaciones que el púrpura tenía en la Edad Media ${ }^{108}$. Y, para finalizar con los ejemplos, dos obras donde sus personajes van revestidos con colores purpúreos excepcionales; por una parte el retablo de la Adoración del Cordero Místico, de los hermanos Van Eyck (Catedral de San Bavón, Gante), donde destacan las magníficas capas pluviales del Papa y los cardenales, y por otro la Virgen de los Reyes Católicos (Museo Nacional del Prado, Madrid, inv. P01260), donde destaca por su intensidad el manto de la reina Isabel con tonalidades que sugieren las más valoradas en Roma si atendemos a los escritos de Plinio ${ }^{109}$ (Fig. 10).

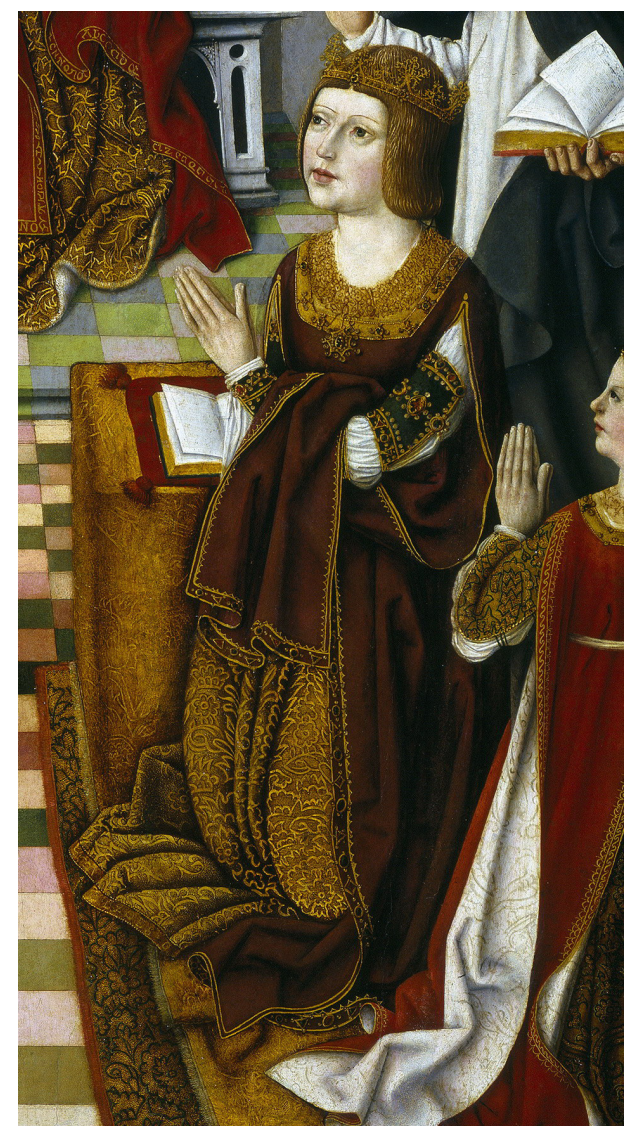

Fig. 10. Virgen de los Reyes Católicos, 1491-1493, Isabel la Católica. Museo Nacional del Prado, Madrid, inv. P01260.

\footnotetext{
108 Sobre el uso de esta prenda en el reino nazarí, véase R. ARIÉ, "El traje musulmán de España en tiempos de los nazaríes de Granada", A la luz de la seda, Madrid, 2012, p. 38.

$109 C f r$. nota 8. San Isidoro de Sevilla también lo cita como más apreciado cuando dice "color est purpurea subnigrae" (Etimologias, XIX, 18, 6).
} 
A modo de conclusión podemos establecer que en la Edad Media el término púrpura no denominaba necesariamente al tinte extraído del murex ni nominaba en exclusividad un color, porque cuando el tratamiento de extracción y elaboración del tinte se perdió, el término se conservó en el lenguaje literario y político como sinónimo de calidad y riqueza. Purpúreo indicaba brillo y refulgencia, cualidades referidas al concepto de belleza, porque participan de la metafísica de la luz al ser una emanación divina, y se reafirmó como uno de los símbolos de poder identificado con la realeza y los príncipes de la Iglesia. Es difícil establecer una única tonalidad cromática, porque esta se halla en función del imaginario colectivo y, por tanto, es susceptible de sufrir variaciones por tratarse de un color impreciso desde su origen. Es por esto que el color de la púrpura en la Edad Media tanto puede ser de tonos violáceos o semejante a la sangre coagulada que decía Plinio, pero según avanza este periodo son los rojos más intensos los que se identifican con el color por ser el quermes la sustancia tintórea más preciada para su obtención.

Es necesario todavía determinar si fue el agotamiento debido a un sistema de extracción intensivo de los caladeros de múrices o las dificultades de su procesamiento para la obtención del tinte lo que propició su sustitución paulatina por el quermes, que fue implantándose como uno de los tintes más preciados en Oriente y Occidente a lo largo de la Edad Media gracias a las rutas comerciales que comunicaban todo el continente desde Estambul al Báltico, hasta convertirse por decreto papal de 1464 dictado por Pablo II en el sustituto de la púrpura cardenalicia, equiparado a partir de entonces con el bermellón ${ }^{110}$.

Haciendo nuestras las palabras de Pastoureau, "el color no es solo un fenómeno físico y perceptivo, también es una construcción cultural compleja [...] el color es, ante todo, un fenómeno social" 111 . La importancia de los colores atiende fundamentalmente a su significado dentro de un contexto cultural o ritual, porque transmiten códigos que ejercen una profunda influencia. Así en la Edad Media, donde hay una especial sensibilidad a la luminosidad, densidad y contraste, se produce la identidad entre color y luz, el color se concibe como brillo que se atenúa en función de los medios u objetos que la luz atraviesa y se valora por su posición entre el blanco y el negro, entre la claridad y la oscuridad. Los términos medievales de color no atienden a matices, al considerarse que estos son consecuencia de la incidencia de la luz o la sombra sobre los colores puros, que los hace parecer diferentes. Los colores puros son luminosos, sólidos y brillantes, por lo que son merecedores de cumplir funciones visuales y rituales y por eso todos los colores no tienen el mismo prestigio y estatus, produciéndose una compleja jerarquización. Este es el sentido en el que tenemos que interpretar la importancia del púrpura, por sus calidades cromáticas y la riqueza de los materiales con que se producía. Por eso a lo largo de la Edad Media no ocasionaría ningún conflicto la sustitución de unas materias tintóreas por otras de similares calidades que conllevaban mantener su suntuosidad avalada por su alto coste.

110 P. FERNÁNDEZ URIEL, op. cit., 2010, pp. 288-290.

111 M. PASTOUREAU, op. cit., 2006, p. 125. 